\title{
International Geological Correlation Programme: An example of collaborative geoscience
}

The International Geological Correlation Programme, which has a relatively small annual budget, is responsible for initiating and completing a remarkably large amount of high-quality research that studies geology both without regard to national borders and in a standardized way. Several projects provide examples of the scientific accomplishments of the over 150 projects that have been supported by this program, which is notable for fostering international collaboration and consequent geological correlation on a global scale. By any measure, the program has achieved tremendous success during its 16 years of existence. (Ed.)

For the last 16 years, something has been happening to the earth sciences that is even more startling and certainly better documented than cold fusion. The International Union of Geological Sciences (IUGS) and Unesco between them have discovered, in the International Geological Correlation Programme (IGCP), the secret of perpetual motion - or, if not quite perpetual motion, at least the way to get something for nothing - or, if not quite for nothing, the way to get an incredibly large amount of high-quality research for an extremely small outlay.

The annual budget of IGCP is about US $\$ 350,000$, of which (once the expenses of regional meetings, the Board, the Scientific Committee, and certain other administrative items have been covered) US $\$ 250,000$ is channeled to more than 50 projects, which is an average of less than US\$5,000 per project. For this US\$5,000, which is barely more than the cost of 2 airfares to a meeting of most projects, one achieves 1,2 , or 3 meetings a year for each project, each meeting involving 20 to 60 people and sometimes many more, which in itself would amount to 50 to 100 times the initial investment. People meet, talk, look at outcrops, and socialize together, and they go away stimulated by what they have seen and heard to perform research at a cost of 100 to 1,000 times the initial investment.

Some of you are probably saying, "Most of this research would have gone on in any case, so why should IGCP take any credit?" Well, this is debatable; although similar work might have been attempted without IGCP, it is not clear that similar work would have achieved the same results. I am going to talk about three projects that I have chosen more or less randomly from those supported by IGCP, as they illustrate very clearly the unique opportunity that IGCP offers to geological research. IGCP is able, in an extremely gentle way, to harness the talent, enthusiasm, and money of researchers in one or several widely separated fields, focus them on a problem, and enable them to see and realize the benefits to be obtained by collaboration and consequent correlation on a global scale. IGCP does this because the problems are defined by the scientists themselves, and the control is by the individual scientists; there is no direction, merely the lubrication that comes from the small amount of money provided and the legitimacy that the names of IUGS, Unesco, and IGCP confer.

The first project that I want to mention is IGCP Project 200, which terminated in 1988 . The aim of this project was to identify and quantify processes of sea level change by producing detailed local histories that can be analyzed and correlated for tectonic, climatic, tidal, and oceanographic fluctuations. This was achieved by (1) the collection and analysis of new and existing sea level data; (2) the survey and data analysis of coastal and shelf deposits to provide information on resources, coastal land use, land subsidence, and land reclamation; and (3) the analysis of tide gauge records and the modeling of other short-term sea level fluctuations. This project stemmed from its predecessor, Project 61 , which showed that a graph of mean sea level during the last 15,000 years was illusory, that there is no single curve, and that this is true for all time scales.

On a scale of 100,000 years, tectonic effects predominate. On the scale of 1,000 to 10,000 years, the elevation versus time plot of more than 4,000 radiocarbon-dated sea level indicators (fig. 1) shows that glacio-eustatic sea level rise is exceeded by vertical movements of land. Formerly glaciated areas reveal late glacial sea levels of more than $200 \mathrm{~m}$ above the contemporary datum, whereas zones marginal to these indicate levels as much as $160 \mathrm{~m}$ below the same datum. Thus, the sea level geoid of late glacial age exhibits a relief of $360 \mathrm{~m}$, more than twice the greatest estimate of glacial eustatic rise. On a 50- to 100-year time scale, if the Earth's surface is divided into a $30^{\circ}$-latitude by $30^{\circ}$-longitude grid (fig. 2 ), the average values of secular linear trends deduced from tide gauge records differ greatly from compartment to compartment and show no general trend.

The applications of the detailed analysis of sea level change undertaken by Project 200 included assisting in the planning of coastal development, such as port facilities and industrial and recreational facilities, in order to produce plans that are compatible with the predicted evolution of the coast. Also, the Environmental Protection Agency of the United States estimated recently that, as a result of $\mathrm{CO}_{2}$ buildup in the atmosphere, the global sea level will rise 5-17 $\mathrm{cm}$ by the year $2000,24-117 \mathrm{~cm}$ by 2050 , and $56-345 \mathrm{~cm}$ by 2100 . Because so much of the world's population lives within a few meters of sea level, this effect could, of course, be catastrophic; however, global temperature has tended to fall rather than rise from about 1940 to 1980 , and only in the 1980 s are there some unequivocal indications of warming. In addition, no sign shows yet in the record of a global acceleration in the rise of sea level. This is not to say that it will not start soon, and the worldwide data base that the project pro- 
duced is an absolutely essential background for monitoring the potential future catastrophe.

The next project that I am going to consider, Project 233, is entitled "Terranes in the Circum-Atlantic Paleozoic Orogens." Members of the project have produced a series of maps of these terranes and a 1:5,000,000 compilation on a Permian palinspastic reconstruction (when the Atlantic Ocean was closed). These are, unfortunately, too large to reproduce here but have already been printed and were shown at the International Geological Congress (IGC) in Washington, D.C., in July 1989. This is the first substantial contribution to the IUGS Circum-Atlantic Project. Terranes have been categorized on the basis of age and tectonic setting. Conclusions of the project are that the major cratonic terranes, and their miogeosynclines, are separated structurally from the magmatic arc and oceanic terranes. These two types of terranes occur in the internal and structurally uppermost parts of the various orogens. Disrupted terranes are made up of ophiolite blocks and oceanic and periarc rocks set in a foliated matrix of miogeosynclinal affinity. They generally occur around the margins of the major cratonic terranes.

The Precambrian rocks of cratonic terranes show a wide range of ages. The "Grenville" rocks (metamorphism at 1 Giga-annum (Ga)) can be identified in Baltica, Laurentia, and South America but are absent in northwestern Africa. Late Precambrian terranes are linited to central and western Europe, the southern British Isles, the southeastern Appalachians, northwestern Africa, and northern South America. They transect Precambrian rocks ranging in age from Archean to Middle Proterozoic.

Magmatic arc and periarc terranes are well preserved in some if the late Precambrian-Cambrian orogens. in contrast to their poorer preservation in Paleozoic orogens. Because these terranes lie on the upper plate and because they probably would be removed by erosion following continental collision and telescoping, their preservation in

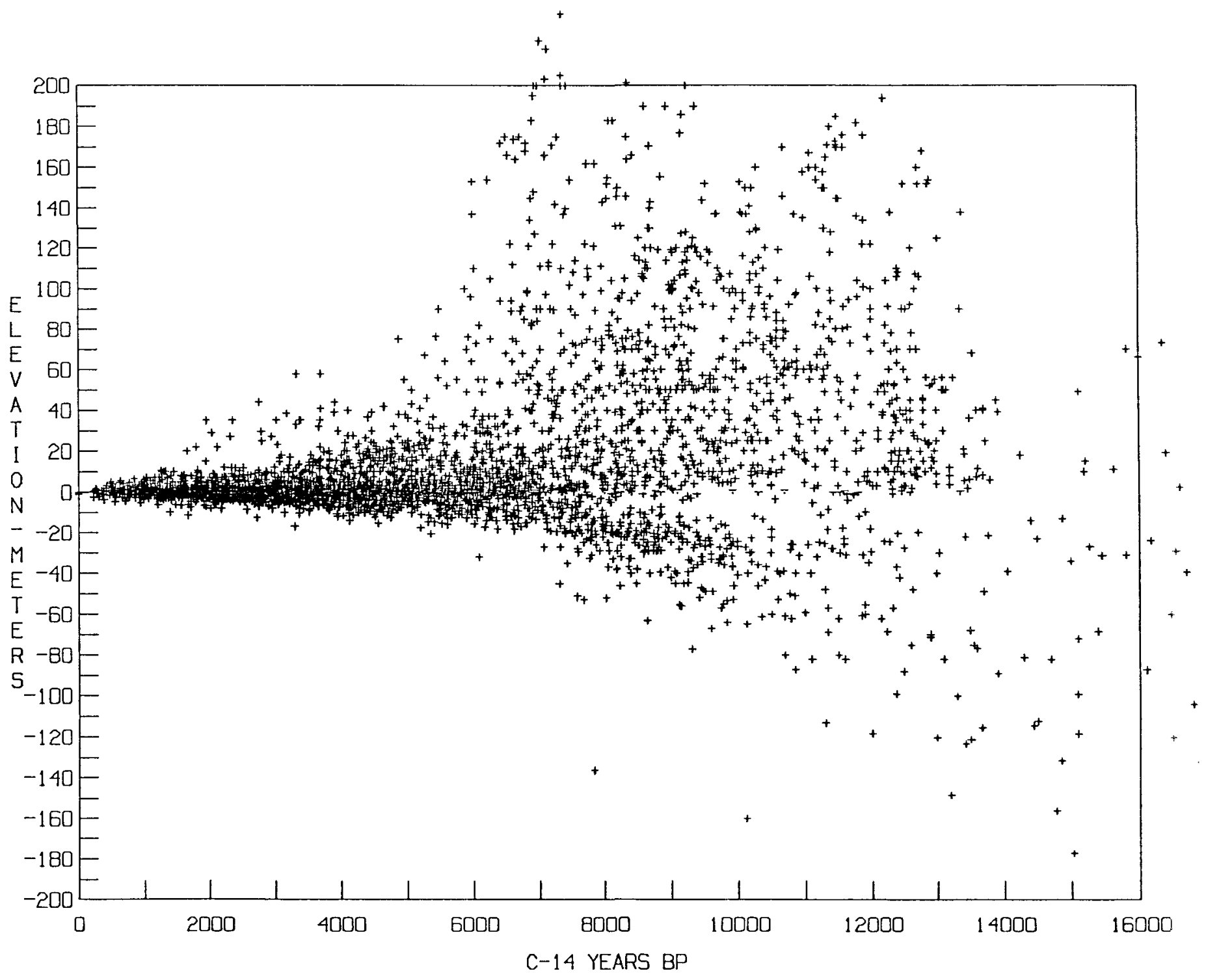

Figure 1. - Elevation versus time plot of radiocarbon-dated indicators of sea level for the past 16,000 years. After the work of W.S. Newman quoted by Pirazzoli (1987). 


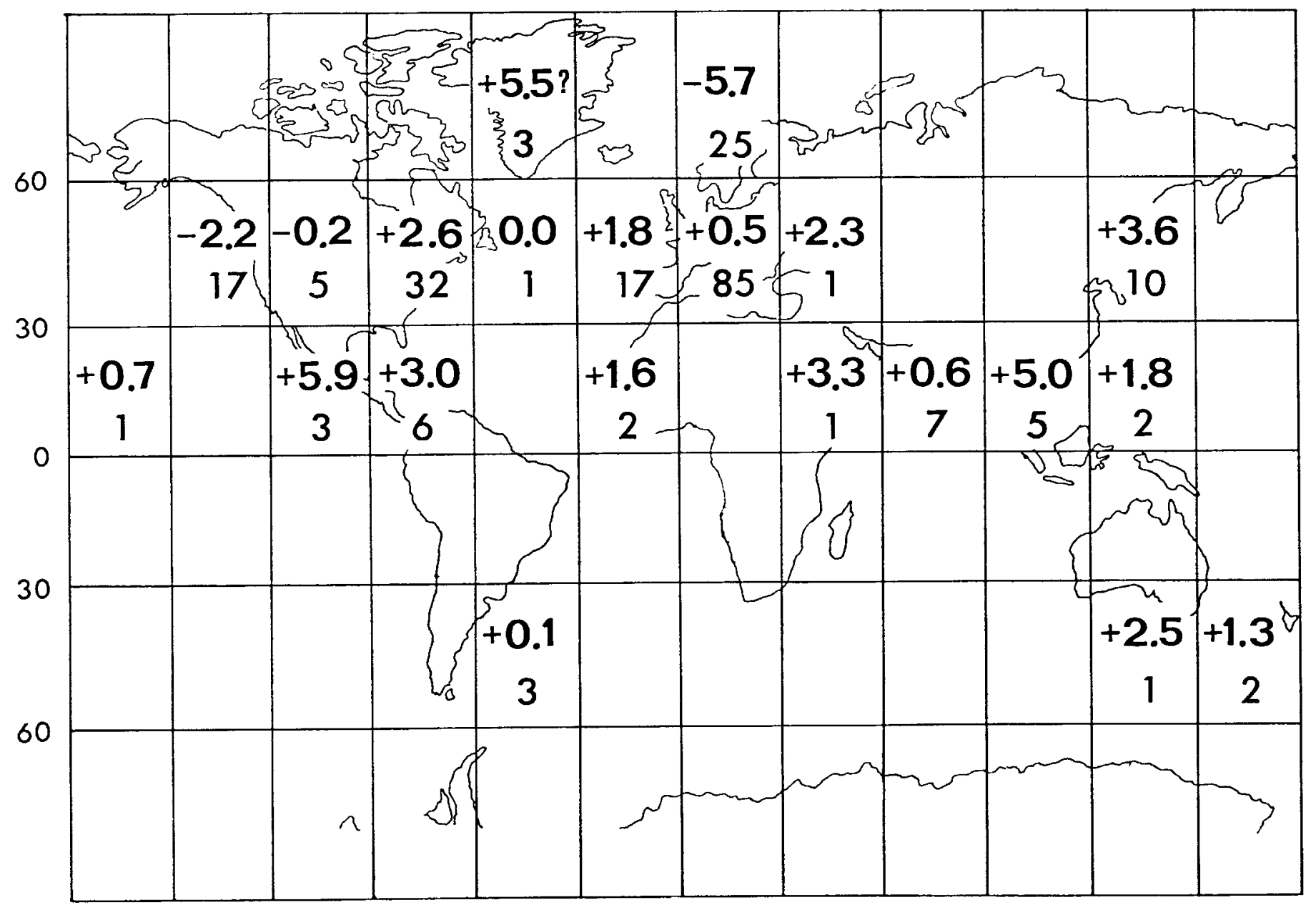

Figure 2.-Long-term linear trends of relative sea level change determined from tidal gauge data averaged for $30^{\circ}$-latitude by $30^{\circ}$-longitude compartments of the world. Larger numbers give average values (in $\mathrm{mm} / \mathrm{yr}$ ), and smaller numbers correspond to the number of stations used for observation in each compartment. Taken from Pirazzoli and Suter (1986).

the late Precambrian-Cambrian orogens suggests that collision did not occur.

Paleozoic ophiolitic, magmatic arc, and oceanic terranes in the Circum-Atlantic Phanerozoic orogens appear to have formed mostly during the Cambrian to Ordovician, and very few formed during the Silurian to Carboniferous. This suggests that Iapetus was closed by the end of the early Paleozoic. This conclusion is supported by the existence of distinct faunal provinces in the Cambrian to Ordovician that were followed by a cosmopolitan fauna in the Silurian to Devonian. Late Paleozoic orogenic movement is inferred to be mainly transpressive along vestiges of Iapetus, while convergence was still occurring in the Variscan orogen and southern Appalachians.

The last project that I want to talk about is Project 257 that is concerned with mafic dyke swarms, some of which, like the Mackenzie dated at $1.267 \mathrm{Ga}$ in northwestern Canada, are of enormous size, in this case $106 \mathrm{~km}^{3}$. These mafic dyke swarms are found cutting Precambrian shields on every continent and were injected periodically throughout geologic time, although the project concerns itself with those of Proterozoic age.

In the 2.54-Ga Matachewan dyke swarm in Ontario, Canada (shown in fig. 3 ), dykes that branch to the north are twice as com- mon as those that branch to the south (fig. 4). The Matachewan dykes cut across the Kapuskasing gneiss zone in the region marked $\mathrm{KSZ}$ in figure 5. This zone consists of a metamorphic belt in which the grade increases eastward from greenschist facies in the west to reach granulite grade before dropping abruptly to greenschist again across a major zone of disruption (the Ivanhoe Lake clastic zone or ILCZ). This is interpreted to be a section down through uplifted continental crust. Polarity studies on the Matachewan dykes (fig. 5) show that, unlike the dykes outside the zone, the dykes inside are exclusively of normal polarization. This could record either uplift exposing younger dykes or remagnetization of deeply buried dykes. Normal dykes cut reverse ones outside the zone, which indicates that those of normal polarity seem to be younger and, therefore, that the first interpretation is the correct one.

A last look at dykes in figure 6 shows a worldwide compilation of dyke ages by continent. Some minimum periods of dyke intrusion show up clearly. Once again, this project points up the necessity of looking at geology both without regard to national borders and in a standardized way.

You have seen details of only 3 of the more than 150 projects that have been supported by IGCP in its 16 -year life span. I could 


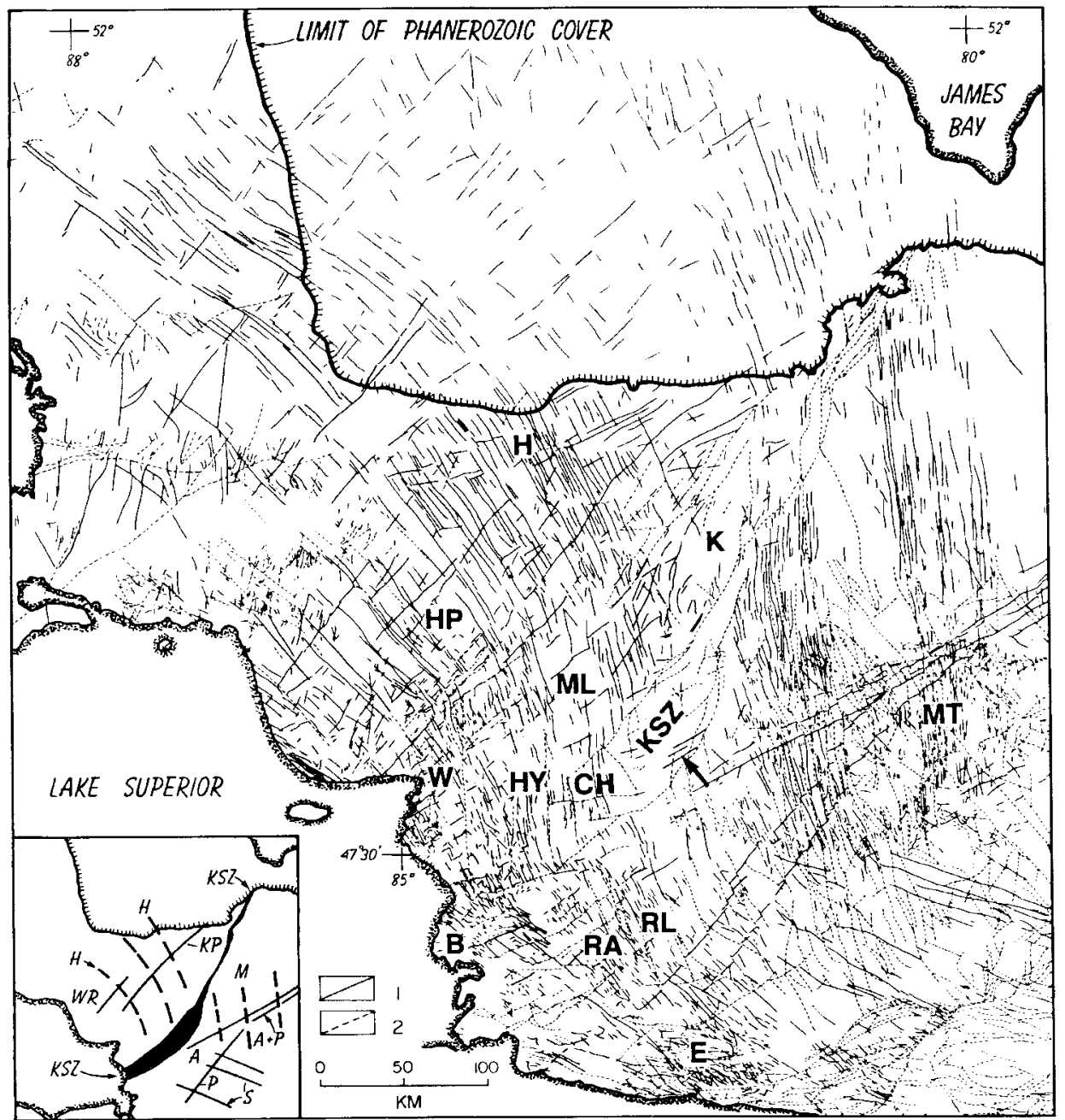

Figure 3.-General distribution of dyke swarms in Ontario, Canada, modified from Ernst and Halls (1984). The western half of the 2.45-Ga Matachewan swarm ( $H$ and $M$ in inset) is deflected across the Kapuskasing structural zone (KSZ), probably as a result of deformation associated with the formation of the zone about 2 Ga. Matachewan dykes all have north to northwest trends. Legend: 1 , dyke; 2, fault. Other letters refer to locations where samples for paleomagnetic study were obtained (Halls and Palmer, 1990).

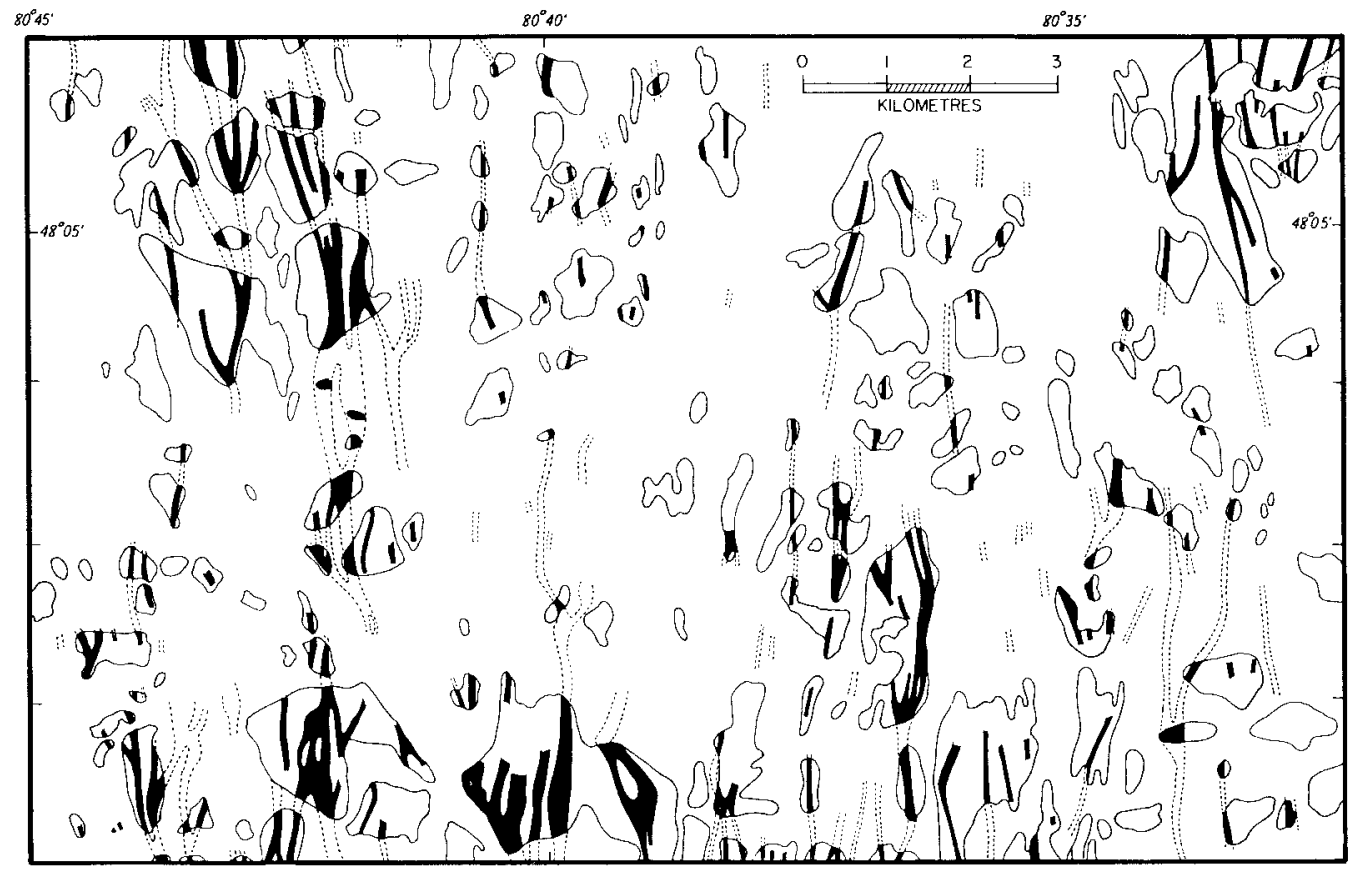

Figure 4. - Detailed map of part of the Matachewan dyke swarm near Matachewan (MT in fig. 3). Areas of outcrop are outlined, within which dykes are shown in black. Note that northwardbranching dykes outnumber southward-branching ones by about 2 to 1 . A similar bias toward northward branching has been found in three other locations within the Matachewan swarm where detailed mapping has been carried out. Diagram taken from Halls (1982). 


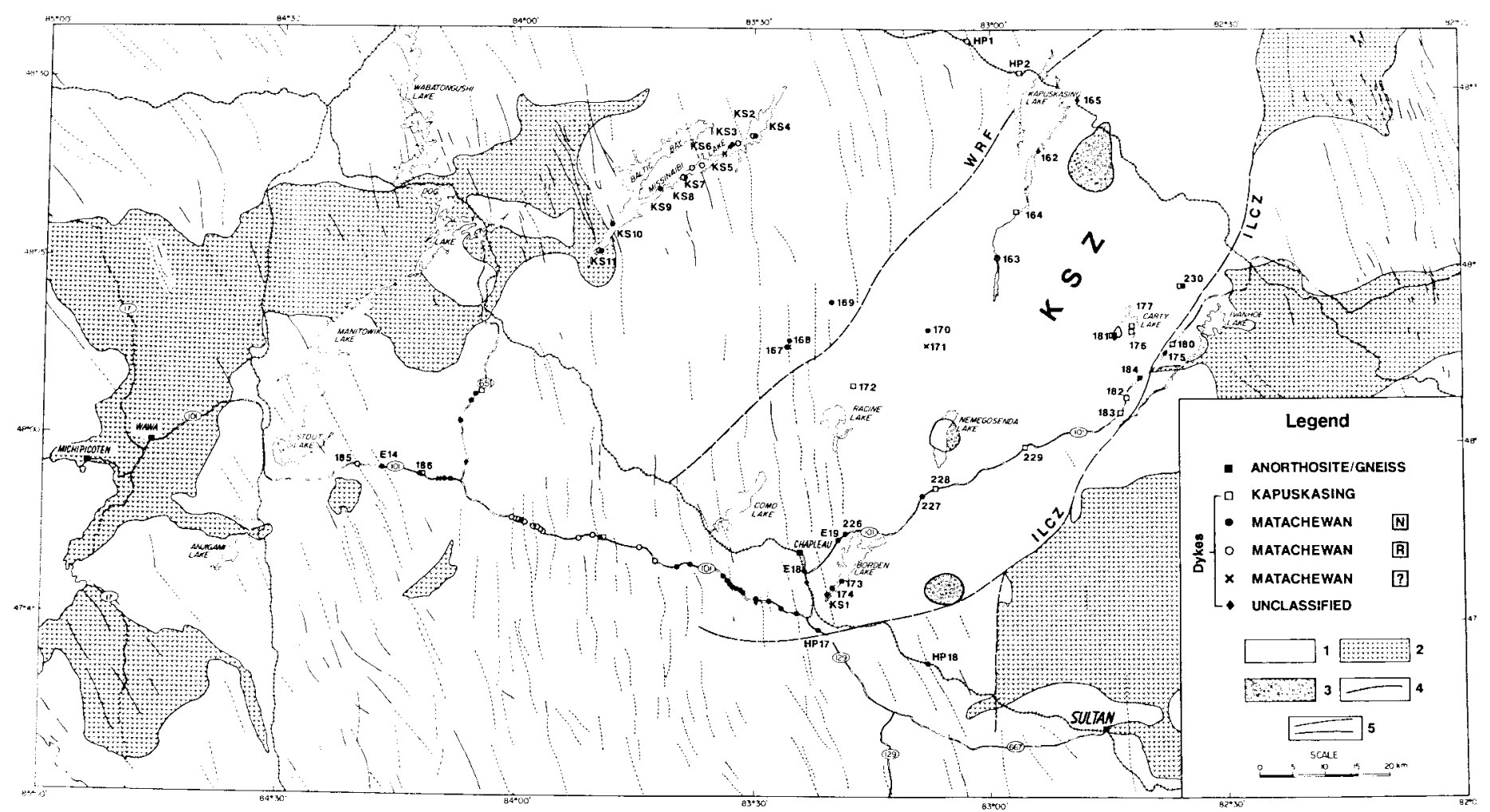

Figure 5. - The distribution of sampled Matachewan dykes, distinguished on the basis of their paleomagnetic polarity ( $N$, normal; R, reversed; ?, unknown). South of Sultan (southeast corner) and extending westward to Lake Superior (fig. 3), $R$ dykes outnumber $N$ dykes by more than 4 to 1 . Dykes within the Kapuskasing structural zone (KSZ) are all $N$, which indicates a major polarity discontinuity to the north and south, probably represented by the Wakusimi River fault (WRF) and the Ivanhoe Lake clastic zone (ILCZ), respectively. Legend. 1. granite, gneiss; 2, greenstones; 3, alkaline complex; 4, fault; 5, dyke, mapped (solid) or defined by aeromagnetic data (dashed). Diagram taken from Halls and Palmer (1990).

have chosen almost any of the 150 as illustrations of the vital need for international collaboration. Indeed, one of the criteria for project selection is how essential is collaboration of this kind to the aims of a project.

In February 1989 in Paris, the Scientific Committee and the Board of IGCP considered 24 new proposals for projects, the most ever. More important than this, the quality was judged to be amongst the best ever. We have ended up with 55 ongoing projects instead of 50. the number we traditionally support. The problems of adequate funding are compounded by the fact that. rather understandably, the new Director General of Unesco, Dr. Frederico Mayer, wishes to undertake some new initiatives, and he has levied a 10 -percent reduction of all existing Unesco budgets in order to free up some financial resources for these initiatives. IGCP is particularly fortunate in that it has been recognized by the United States and the United Kingdom governments as being worthy of support, despite their withdrawals from Unesco. Funds that normally would have been contributed through Unesco have been funneled to IGCP through II GS. The funds from these two countries now account for 40 percent of the money that finds its way directly to projects. You can appreciate how extremely important this support has been and will continue to be.

At the same time, you have seen the very unique opportunities that IGCP offers our world of earth scientists and, through us, the world at large. We would never have had the overview of dyke swarms that we have if it were not for IGCP. Our understanding of lapetus has been increased greatly by the international cooperation afforded by the program. And the meticulous documentation of sea level changes around the world is producing a data base that is essential to anyone who has a long-term concern for the billions of people who live within a few meters of present sea level.

Because established research funding sources can be harnessed, all of this comes for a pittance. Think of how much money would be required to accomplish a goal such as that being achieved by the sea level project by the traditional route of creating a division within a government organization. Think also of the difficulty of killing such a division once it outlived its usefulness and became a scientific white elephant. IGCP projects, on the other hand, self-destruct once their preordained life term is exhausted, occasionally to rise from the ashes of the old project if a real need still exists. The vitality of the program and the important role that it plays within earth science today, as you have seen here, are evidence of the wisdom of its founders 16 years ago and of the dedication of its supervisors, initially Dr. Felix Ronner, then for many years Eckart von Braun, and more recently Dr. Endre Dudich.

\section{Acknowledgments}

I am grateful to Drs. P.A. Pirazzoli of IGCP Project 200. J.D. Keppie of IGCP Project 233, and Professor H.C. Halls of Project 257 for assistance with illustrative material both for my plenary address at the IGC in July 1989 and for figures for this printed version. I also thank Dr. Endre Dudich for his constant assistance with all matters connected with IGCP. 


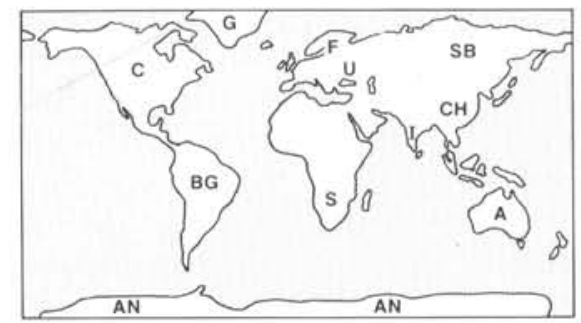

MAJOR PERIODS OF THOLEIITIC DYKE ACTIVITY (Ga).

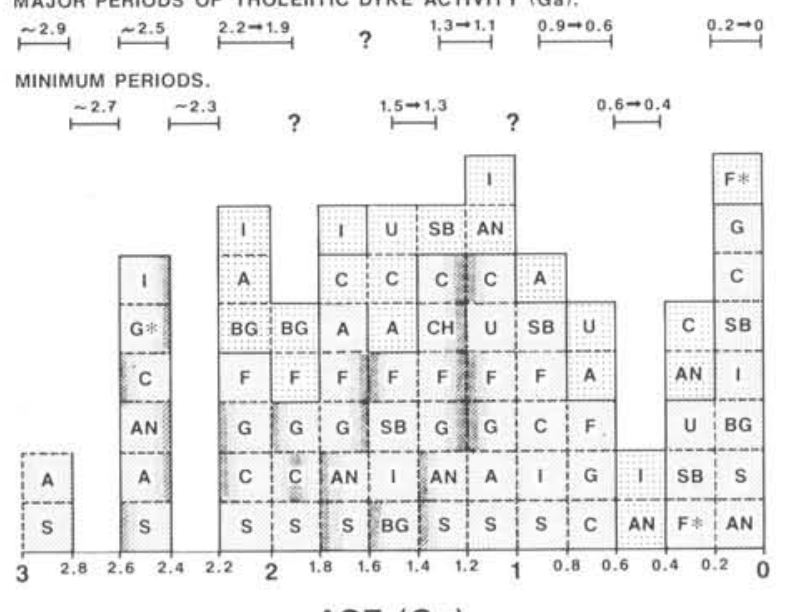

AGE (Ga)

Figure 6. - Summary of radiometric age data for mafic dyke swarms of the world taken from Halls (1987). No account has been made of the degree of reliability of the data, although, in general, the more uncertain data (in terms of primary age and known precision) come from South America, USSR, People's Republic of China, and India. Symbols: A, Australia; AN, Antarctica; BG, Brazilian-Guyanan shield; C, Canada and USA; CH, People's Republic of China; G, Greenland; F, Fennoscandia; $G^{*}, F^{*}$, Greenland and Fennoscandia including the British Isles; I, India; SB, U, Siberian and Ukrainian shields; $S$, southern Africa. Extent of dyke intrusion increases with degree of shading in diagram.

\section{References}

Ernst, R.E., and Halls, H.C., 1984, Paleomagnetism of the Hearst dike swarm and implications for the tectonic history of the Kapuskasing Structural Zone, northern Ontario: Canadian Journal of Earth Science. v. 21, p. 1499-1506,

Halls, H.C., 1982. The importance and potential of mafic dyke swarms in studies of geodynamic processes: Geoscience Canada, v. 9, p. 145-154.

1987, Dyke swarms and continental rifting: Some concluding remarks, in Halls, H.C., and Fahrig, W.F., eds., Mafic dyke swarms: Geological Association of Canada Special Paper 34, p. 483-492.

Halls, H.C., and Palmer, H.C., 1990, The tectonic relationship of two Early Proterozoic dyke swarms to the Kapuskasing Structural Zone: A paleomagnetic and petrographic study: Canadian Journal of Earth Sciences. v. 27, p. $87-103$.

Pirazzoli, P.A., 1987, Project 200: Sea-level correlation and applications, in Skinner, B.J., ed., Geological correlation: Scientific achievements 1983-1987: Paris, Unesco, Special Issue for International Geological Correlation Programme, p. 90-93.

Pirazzoli, P.A., and Suter, J.R., eds., 1986, Late Quaternary sea-level changes and coastal evolution: Journal of Coastal Research Special Issue 1, 100 p.

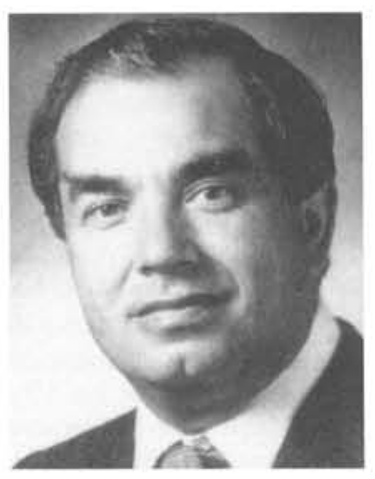

Dr. Tony Naldrett was born in England and educated at Cambridge University, after which he migrated to Canada. He obtained advanced degrees at Queen's University and in 1967 joined the University of Toronto where he teaches and studies the geology of mineral deposits, especially nickel, copper, and platinum-group element deposits. In 1977 he was a founder of IGCP Project 161 (Magmatic Sulfide Deposits in Mific and Ultramafic Rocks) and was its leader until 1986, when he was appointed to the IGCP Board, where he is now Chairman. He is Chairman of the International Mineralogical Association's Commission on Applied Mineralogy and President-elect of the Society of Economic Geologists. 